\title{
Professionally Oriented English Teaching of Future Aviation Industry Professionals
}

\author{
Qabas Jameel Rashid ${ }^{1, *}$, Natalia Teslenko ${ }^{2}$ \\ ${ }^{1}$ Department of English, College of Art, IMAM Jaafar Al-Sadiq University, Baghdad, Iraq \\ ${ }^{2}$ Department of Modern European Language, Kyiv National University of Trade and Economics, Kyiv, Ukraine
}

Received July 4, 2020; Revised September 27, 2020; Accepted October 19, 2020

\begin{abstract}
Cite This Paper in the following Citation Styles
(a): [1] Qabas Jameel Rashid, Natalia Teslenko, "Professionally Oriented English Teaching of Future Aviation Industry Professionals," Universal Journal of Educational Research, Vol. 8, No. 11B, pp. 5768 - 5778, 2020. DOI: 10.13189/ujer.2020.082211.
\end{abstract}

(b): Qabas Jameel Rashid, Natalia Teslenko (2020). Professionally Oriented English Teaching of Future Aviation Industry Professionals. Universal Journal of Educational Research, 8(11B), 5768 - 5778. DOI: 10.13189/ujer.2020.082211.

Copyright $\odot 2020$ by authors, all rights reserved. Authors agree that this article remains permanently open access under the terms of the Creative Commons Attribution License 4.0 International License

\begin{abstract}
The study is devoted to Aviation English language learning by future aviation industry professionals in the context of obligatory disciplines which are of vital importance for future specialists in the aviation industry professional activity. Aviation English language learning determines the readiness and ability of future specialists in the aviation industry to conduct dialogue both in the native and in English aviation languages, first of all, in direct professional activity. The main purpose of the investigation is to figure out the effective approaches and teaching methods of professionally oriented English vocabulary for the students of aviation industry and to develop a new program strategy for the introduction of communicative methods and techniques in Aviation English teaching of future aviation industry professionals. The leading methods which were used during the investigation are online and paper questionnaire of Aviation English teaching in National Aviation University; online and paper questionnaire of students on the effectiveness of the use of communicative training excesses in the classroom; statistical processing of the data obtained, individual and collective interviews with the teachers of foreign languages, video, presentations, usage of the Moodle platform and Google classroom. The investigation has two types of result: theoretical and practical. The theoretical overview has shown that future aviation professionals' training is guided by regulations on air navigation in accordance with the standards and recommended practices of the International Civil Aviation Organization. The practical results of the study, presented in the investigation, proved
\end{abstract}

out that the most approaches of Aviation English teaching of future aviation industry professionals are the competence, communicative and contextual. The dominant method for professionally oriented Aviation English teaching are communicative training methods, which were suggested for improving English proficiency of future aviation industry professionals, has proved out its quality and effectiveness. "The professionally oriented Aviation English learning program for the aviation industry students" which was developed by the author in the process of investigation promotes further proficiency of future aviation industry professionals is significant in contributing to air transportation safety. The main conclusions of the provided investigation show that the development of English-language communicative language skills of future aviation industry professionals to the high point demands the organization of a qualitative educational environment of universities, which should help students to adapt to the English-language academic, professional and information environment.

Keywords Professionally Oriented English, Aviation Industry Professionals, Teaching Methods, Aviation English Teaching, Communicative Language Skills, Learning Program

\section{Introduction}

The development of the modern world's communication 
and international socio-economic and cultural interrelations provides the increasing of airlines' number in different countries, expanding of air-travelling services that are formed according to different social needs of customers, expanding of destinations and routes etc. Along with the expansion of international communication and cooperation in all spheres of human's life (economics, business, diplomatic relations, education, science, business, travel), air travelling safety is an extremely important aspect in this context, which is determined by a number of factors, including: aircraft technical characteristics; weather conditions; professional competence of pilots, air traffic controllers and support staff (pilots' skills in managing airplanes; ability to evaluate various situations critically in the course of professional activity; in the process of performing their professional duties; communication skills and foreign language competence, etc.). However, the pilot is the most important factor in the list, as safety and comfort of flight depend on his professionalism. According to the regulations of the International Civil Aviation Organization, one of the most important components of aviation pilot's professional proficiency is a thorough knowledge of Aviation English and free communication in English [1]. Therefore, the modern system of English-language professional training for aviation industry professionals is aimed to find out new, effective and scientifically grounded approaches of learning Aviation or professionally oriented English at an advanced level.

\section{Professional training}

In the European context, foreign language education and communication language skills of professionals in different industries can be considered in different aspects of professional training. According to the recommendations of the Charter of the Council of Europe on Education for Democratic Citizenship and Human Rights Education of 11 May 2010, “... human competence is not limited to the cognitive component; functional aspects of professional activity (availability of technical skills), interpersonal (social or organizational skills) and ethical values are included in the structure of the concept, but involves foreign communicative language skills as well [2]. As the future training of future aviation professionals is guided by regulations on air navigation in accordance with the standards and recommended practices of the International Civil Aviation Organization [1]; regulatory documents of the European Aviation Safety Agency [3]; Report on the regulatory requirements of the Joint Aviation Authority of Europe [4]; the content of the Chicago Convention on International Civil Aviation [5]; recommendations of the European Commission for the Safety and Improvement of Air Travel [6]. Studying English aviation language is an obligatory requirement for the professional activity of future specialists in the aviation industry, which determines the readiness and ability to conduct dialogue in native language and in Aviation English language, first of all, in the process of professional activity.

The analysis proves out that there is necessity to develop the methodological approaches, content and methods of professionally oriented Aviation English teaching of the aviation industry professionals, specifying the difficulties and outlining the stages of such training, which has formed the main purpose of the investigation presented in this article.

\section{Research Questions}

Within the framework of the problem, we must solve the following specific scientific tasks:

- to study effective approaches and teaching methods of professionally oriented English vocabulary for the aviation industry students;

- to describe "The professionally oriented Aviation English learning program for the aviation industry students" and teaching methods for the effective teaching;

- to study the levels of future aviation industry professionals' communicative English-language skills;

- to present an analysis carried out in the context of this investigation, which will reveal actual state of things and will help to develop a new program strategy for the introduction of communicative methods and technics in the teaching of Aviation English of future aviation industry professionals.

\section{Tasks and content of work}

To conduct an online and paper questionnaire of future aviation industry professionals on the theme "Aviation English knowledge and communicative skills", which will allow to distinguish the indicators of Aviation English knowledge, apprehension, communicative skills and percentage of students who have high, medium and basic levels.

To conduct an online and paper questionnaire of future aviation industry professionals on the theme "Effectiveness of the communicative training exercises using for Aviation English teaching".

To introduce modern, innovative, professionally oriented Aviation English learning program in the process of aviation industry students' training and further connection of the acquired knowledge in professional application.

\section{Materials and Methods}

The research is based on an experimental method; measurement tools and procedures of which (specially designed questionnaires) were focused on establishing the influence of gender factors on the formation of future 
profession image among the university students (on the example of future lawyers). Determining and describing the characteristics, selected for the experiment, made it possible to put them uniquely in ordinal scale, to highlight the linear arrangement of objects on some real line, and to make ranking. Factor analysis and variance analysis were used to process and interpret the measurement results. Faculty of Law of National Aviation University became an experimental basis for conducting the sociological research, and the respondents were first-year students majoring in "Law".

The specificity of the suggested research is connected with the introduction of new approaches to the program's content formation and methods of Aviation English teaching, thus the research is based on the latest teaching and learning technologies that include the most influential and dominant scientific opinions and statements presented in the publications from different countries. The problems of vocabulary, grammar and stylistics material for different professional needs and purposes of different professionals were discussed at the Main international congresses of foreign language teachers [7] and forums in the field of education [8] and are presented in the OECD researchers' reports [9]. These are the investigations of creating a new style of Aviation English teaching and learning, changing the algorithm of the educational process participants, the development of psycho-pedagogical support of English language learning, which is based on modern programs' content formation and aids of teaching [10-12].

The current state of research publications in the field of the introduction of new approaches to the program's content formation and methods of Aviation English teaching is taken into consideration. Special attention is drawn to the innovative, motivational and active communicative approach in education, as reflected in the most cited works of such researchers as Liu \& Kleinsasser [13], Takacs et al. [14], Mikheeva \& Dvoryadkina [15], Ragan [16], Estival \& Molesworth [17], Mc Grath [18], Kukovec [19] and others.

For implementation of the research we have used the following Quantitative research methods:

- online and paper questionnaire of Aviation English teaching in National Aviation University;

- online and paper questionnaire of students on the effectiveness of the use of communicative training exercises in the classroom;

- $\quad$ statistical processing of the data obtained.

Qualitative research methods:

- individual and collective interviews with foreign language teachers;

- video, presentations, usage of the Moodle platform etc.

\section{Findings}

\section{Conceptual approaches to professionally oriented English teaching aviation industry students}

Developing English proficiency when training future aviation industry professionals is significant in contributing to air transportation safety. Language proficiency does not merely mean knowing vocabulary, grammar rules and norms of pronunciation. It is a complex interaction of a number of skills and abilities, which constitute person's communicative language skills [20]. In this context, the effective approaches for Aviation English teaching should be taken into account, as they influence the English-language communicative language skills, which we distinguish as the knowledge of the linguistic and not linguistic rules of communication and the skill to use such knowledge effectively and appropriately in real life situations for the purpose of fulfilling communicative goals [21]. We will delve into the components of communicative language skills in the framework introduced by Canale and Swain [22]: grammatical competence (this competence includes knowledge of lexical items, rules of morphology, syntax, grammar and phonology); sociolinguistic competence (the component of the communicative language skills is made up of sociocultural rules of language use, the knowledge of social rules is essential for producing and apprehension utterances that are appropriate to the context in which language is used); strategic competence (this component is made up of verbal and non-verbal communication strategies that may be called into action to compensate for breakdowns in communication); discourse competence (the component represents the ability to combine language structures and language functions into a coherent and cohesive text). The Aviation English learning the lexical competence alongside with pronunciation and structure/grammar provides the foundation for fluency and comprehension skills of future aviation industry professionals. The mentioned competencies are further combined to ensure proficiency in interaction.

It is possible to form the English-language communicative language skills with the usage of competence approach, which involves the list of educational competences, is seen as a requirement as a given social standard of education for the student necessary for its further effective functioning in a certain sphere of human activity. Since the acquisition of these competences occurs gradually in the course of learning, the level of competence of the student at different stages of learning will be different [20]. 
When we speak about English-language communicative language skills, it is inevitable to ignore the communicative approach in Aviation English teaching process. Communicative approach in Aviation English teaching is known as "a view on the components and their justification on the basis of socio- and psycholinguistic vision, recognition that a language being a tool of human communication functions, is acquired and standardized in the normal process of interaction, lives in contacts between people..., the communicative approach includes the selection of learning material, production of the system of exercises, development of the scheme of curricular and extracurricular classes" [23, p. 35]. According to Passov [24], main principles of communicative language teaching methods are the following: speech-intellectual activity, individualization, function-based character, situation-based character and innovation [24].

The process of foreign language studying involves a contextual approach, which is considered by scientists as a conception of teaching and learning that helps teachers relate subject matter content to real world situations and motivates students to make connections between knowledge and its applications to their lives as family members, citizens, and workers and engage in the hard work that learning requires [25]. Thus, in the context of our research it means that future aviation industry professionals know the specificity of the language use and will obtain the extra-linguistics language knowledge.

All the mentioned approaches are characterized by the high level of importance not only from the pedagogical point, but also, they are mentioned and determined as the obligatory approaches in the Guidelines for Aviation English Training Programmes [20].

\section{The professionally oriented Aviation English learning program for the aviation industry students}

In the context of the research "The professionally oriented Aviation English learning program for the aviation industry students", five main modules were divided into eleven topics.

The first module consisted of such units as: "Giving orders, making requests and offering to act"; "Giving advice, asking for permission, giving undertakings". The units were aimed at obtaining knowledge about everyday communications between different professionals of aviation industry, as well as the main duties and functions of each person, who works in the air company. The students studied new vocabulary in groups: "dwellings and appliances", "aircraft safety", "airport work and jobs' features", "professional relationships". We were focused on the study of simple tenses (Present and Past Simple), as well as the possibility of communication on everyday topics.

The second module was devoted to two important aspects of modern future aviation industry specialists' communication: "Providing information about the past, present and future; describing intentions" and "Discussing necessity, capacity, feasibility and possibility". Grammar, future tenses, construction of comparisons and certain groups of phrasal verbs are considered.

In the third module, students learnt topics related to "Managing pilot-controller dialogues", "Managing air traffic sequences", "Managing flight attendant and pilot-controller dialogues between each other and with passengers". The topics also included the problems of health care, everyday routine and various criminal dangers etc. By the lessons "health problems", "stress and relaxation", "feelings", "types of offense", new vocabulary was studied and new apprehension on this subject was built, including knowledge of modal verbs and the use of tag-questions.

The fourth module was aimed at strengthening knowledge in the field of acknowledging, confirming, correcting, reading back, assessing, describing states and processes. Students repeated the previously studied turnover and learnt communications in the professional sphere, expanded the vocabulary of the directions and different commands. Students discussed causative form and reported speech in video blogs.

The final module included questions of resolving conflicts, paraphrasing and clearing ambiguity. In this context, such topics as "types of conflicts", "free-time activities", "types of entertainment," "types of messages" were considered. During the lessons, the teacher introduced the use of such grammar structures as Conditional Mood, Future Perfect, "wish" and "would rather".

The full course was aimed at the holistic acquisition of communicative skills. In the context of each lesson, the students went through all aspects of the aviation language speaking, listening, reading and writing. Each task was related to different activities and professional situations. Concerning grammar, the teacher gave the opportunity for students to make their mental maps that helped to learn a complex group of words or phrases for use in a communicative environment (as an example, the task to make a dialogue, where each student was required to use ten or more new words from the unit etc).

\section{Experimental work}

350 students and 20 university teachers took part in the research. They were suggested program of professionally oriented English learning program, which included the communicative training exercises. For 6 months, future aviation industry professionals had been studying Aviation English: main aviation technical terminology, communication between crew members, communication between pilots and controllers, communication of flight attendants with passengers etc.

The experiment was carried out in 2 stages: Ascertaining 
stage and Formative stage. At the first stage, the diagnosis of levels of Aviation English communication skills was carried out by future specialists in the aviation industry. The first stage of the investigation included the online and paper questionnaire of future aviation industry professionals on the theme "Aviation English knowledge and communicative skills". The results of the questionnaire showed that only 10 percent of students were able to use main aviation technical terminology in their communication, these students knew the Aviation English specific terminology quite well and theoretically understood the purpose of communication between crew members, communication between pilots and controllers, communication of flight attendants with passengers, but they were lack of practice. The other 75 percent had very uncertain knowledge about Aviation English and its specifics though understood its priorities for their future professional activity. And the rest of the 15 percent did not quite consider vital importance of the Aviation English learning for future work and safety, but they were eager to learn it for understanding and clarifying their perception of this discipline.

We distinguished the indicators of Aviation English knowledge apprehension, communicative skills and percentage of future aviation industry professionals. These indicators are high, medium and basic levels. At the Ascertaining stage we conducted online and paper questionnaire of future aviation industry professionals on the theme "Effectiveness of the communicative training exercises using for Aviation English teaching".

The Formative stage included two phases: the first one was to pick out the appropriate and effective methods of professionally oriented Aviation English studying for future specialists in the aviation industry; the second phase provided the implementation of "The professionally oriented Aviation English learning program for the aviation industry students". In the context of the first phase it should be noted that modern pedagogical technologies of English language training of aviation industry specialists are based on a combination of linguistic and didactic constants and modern techniques are increasingly gaining international educational space [26]. In the process of the research, the teachers proposed students different types of communicative training exercises. In terms of organization of the process of mastering the system of exercises have been provided by:

a) selection of appropriate exercises relevant to the nature of the skill and quality (mechanism), or other skills;

b) determining the necessary sequence of exercises: mastering always goes through some stage and proceeds to the methodological basis of certain principles or rules;

c) determining the ratio of exercises those or other types, species, subspecies and variants, because it determines the success of not less than the correct sequence of exercises; d) the regularity of certain material;

d) the correct relation (relationship and interaction at all levels of the system [22].

The very interesting complex of exercises was developed by Ukrainian investigator O. Kovtun [27]. In the case of the of Aviation English teachers, the scientist suggested the following typology of exercises will be effective in professionally oriented English learning.

1. Exercises for the formation of extra-curricular skills operative memory development (memorizing and reproduction of words' groups, text fragments, "snow shaft", etc.). Work with such exercises is built on the principle of increasing difficulty. Students are encouraged to memorize and reproduce a series of words, numbers, word combinations with numerals, toponymies, Aircraft Identification, courses, flight levels, meteorological conditions. The number of words may vary (in the direction of increase), although it is advisable to follow the principle of $7 \pm 2$. Words can be selected on a thematic basis or arbitrarily. Exercises can be complicated by the task of switching from one language code to another. This mode of operation corresponds to the mode of operation of the pilot, who perceives flight information in English, but operates it in internal Ukrainian language.

2. Exercise on the clear accent development, speech fluency improvement (working out pronunciation of patter words, reproduction of patterns in the discourse of RTF, etc.). Particular attention should be paid to the language tempo, the correct accentuation of words, the clarity of the diction.

3. Exercises for the development of messages perceive skills in adverse conditions: at the background of different types of obstacles and specially created difficulties (simultaneous listening of the text and reversed order number counting, simultaneous listening of two different languages texts etc.). It is advisable to apply two language codes at the background of complications in the perception of information simultaneously, another option is the perception of information in English, but the information processing should be done in Ukrainian. Learning material perception obstacles may vary greatly.

4. Exercises for the listening ability development / perceive the discourse of RCA (listening to RTF fragment and recording missed words, determining the basic data on the flight run, RTF message apprehension in the context of complicated reception conditions, detection of inaccuracies (errors) in radio broadcasting, retention and reproduction of RTF fragments). The exercises involve a holistic perception and a complete (100\%) apprehension of 
the standard phraseology of the RCA from the first presentation. Skills which are formed during these exercises are as follows: full perception of voice messages; overcoming difficulties in apprehension audio messages, using the knowledge of basic RCA phraseology, code words, probable prognostication; perception of voice information in a natural and fast tempo; memorising and keeping of different intonation messages in the context of one-time presentation etc.

5. Skills-forming exercises to work up the perceived information in the RTF discourse form. The exercises involve listening to RTF fragments, their analysing and finding the communicative mistakes that have become a contributor to aviation events. Mastering the skills of finding errors in the RTF discourse and their future pilots' willingness to follow the radio communications procedures in their future professional activities.

6. Exercises for the RTF techniques training (listening to the RTF dialogue and replication of the air traffic controller, compilation of the RTF fragment on the release of the airplane track/landing, interpretation and simulation of RTF dialogues on the situation, which is proposed by the teacher of English aviation etc.). The systemic usage of such exercises can be complicated by the presentation of uncompleted information, which requires students not only speech skills, but also the involvement of professional intuition, analysis. It means that educational activities are approximated to professional.

7. Exercises for the reflexive-assessment skills formation in the application of RTF discourse (solving situational tasks). The tasks for which students have to apply the skills formed in the previous stages of study are solved. The inability to solve these tasks correctly and promptly (taking into account the expeditious index) indicates the need for further work on forming, adjusting or improving the ability to operate the RTF discourse. Self-reflection and assessment become powerful factors for motivation of students in this context [27].
The structure of the programme included the informational and interactive technologies of English teaching, actually the complexes of exercises which included on the development of video materials in a multidisciplinary television Studio in a team of teacher-student provides an opportunity for a comprehensive study of a specific topic [26]. Different types, species and varieties of exercises were performed in a sequence and in such numbers that take into account the regularities of formation of abilities and skills in various types of speech activity. The highest possible level of knowledge of the OIA should be provided under specified conditions [28].

The exercises ensure the development of communication skills in close to real professional situations, they were based on the principles of intense immersion in the speech situation; exercises provided a rich aviation terminology dialogue and informing; the teacher acted as a director, who asked to play different professional situations students' tasks was to recreate a communicative situation using the appropriate vocabulary, taking into account the correct grammatical formulation of statements, etc.

The vocabulary exercises were developed taking into account the vocabulary teaching practices presented by $\mathrm{M}$. Celce-Murcia and L. McIntosh, the main basis of which is to study the vocabulary in the context of communicative situations [29].

We accomplished the teaching process with the complex of methods, such as the Grammar-Translation method, task-based learning, communicative language teaching, audio-lingual method, suggestopaedia, the total physical response, structural-situational teaching, person-oriented situations etc.

The examples of exercises will demonstrate the approaches which have been used during research and their realisation within the class activities.

1. Exercise for a communicative activity:

- What: helps to create an information gap

- What for: to make communication necessary

- How: simulating real-life situations.

2. Example of activities

Table 1. Types of activities, purposes and learning tools for students

\begin{tabular}{|c|c|c|}
\hline Activity Name & Task Purpose & Context Input \\
\hline Picture Description & to check how well students can make themselves clear & Picture \\
\hline $\begin{array}{l}\text { Listening for Confirmation and } \\
\text { Clarification }\end{array}$ & to check how well students can confirm and clarify & Radiotelephony recording \\
\hline Speculation and Anticipation & $\begin{array}{l}\text { to check how well students can speak on the reasons and } \\
\text { consequences }\end{array}$ & Video \\
\hline Problem Solving Role-play & $\begin{array}{l}\text { to check how well students can report the situation and } \\
\text { state their intentions }\end{array}$ & Cards with non-routine situations \\
\hline
\end{tabular}


Table 2. Communicative phrases and vocabulary for students

\begin{tabular}{|c|c|}
\hline Check-in Assistant & Passenger \\
\hline $\begin{array}{l}\text { - Show your ticket, please? } \\
\text { - Let me look through your passport, please? } \\
\text { - I should inform you, that your passport has expired. } \\
\text { - Do you have another document of identification? Let me see it. Thanks a lot. } \\
\text { - I'm afraid it won't go with the requirements. } \\
\text { - May I have a look to your child's birth certificate? } \\
\text { - Do you have a carry-on bag? } \\
\text { - Excuse me, but you are afraid that bag exceeds the size restrictions. } \\
\text { - What class are you travelling on? } \\
\text { - Do you know the number of the flight? What is the number of the gate you } \\
\text { - Yaur boarding on? } \\
\text { - Unfortunt is expected to take off on time. Don't be late please. } \\
\text { - Dear passengers, Flight } 347 \mathrm{E} \text { to Oslo has been canceled. } \\
\text { - Have a nice flight. }\end{array}$ & $\begin{array}{l}\text { - I've got an e-ticket. } \\
\text { - I'm afraid that I've forgotten passport. Is it obligatory } \\
\text { - Lo show you it? } \\
\text { - Look at these documents, the ticket should be in. } \\
\text { - I requested a child-seat bell for infants. Can you check } \\
\text { to confirm? } \\
\text { - My child is afraid of the security check in? Can I take } \\
\text { - Is child through security with me? } \\
\text { - Is the serving meal on board vegetarian? } \\
\text { - Will they be showing an inflight movie or just few } \\
\text { - Wdvertisement blocks? } \\
\text { - Where can I find a luggage assistant? }\end{array}$ \\
\hline
\end{tabular}

3. The students are proposed to learn different communicative phrases and vocabulary (for example: see in Table 2).

4. The activity of the communication training exercises can include the following interpretations.

Sample of Conversation 1:

Check-in Assistant: Hi. Are you flying to San Francisco tonight?

Passenger: Yes, I have my ticket with me. And I also have the electronic variant of it. Should I show you both of them?

Check-in: Oh, no, the one of it will be enough!

Passenger: Here you are.

Check-in: Great. Now I need to see your passport as well.

Passenger: Excuse me, please, but I was informed that if I have an e-ticket the passport won't be in your need. Oh, that'll be awful, if it's not so!

Check-in: Don't worry, please. Everything is ok. I just need the correct spelling of your name, so I can find you on the computer.

Passenger: Oh, many thanks! It's Cornier. Elisabeth Cornier.

Check-in: Great. Everything is correct now and I've found you in the list of passengers. Here we are. Oh, you're travelling with a child today.

Passenger: Yes, with my nephew Brain. He's 10 years old.

Check-in: All right. Will you show me your nephew's birth certificate to prove that he is under 16 years of age.

Passenger: Here you are. Take please.

Check-in: Thank you. Do you have the over-sized luggage or are you just checking these two small-sized bags today?

Passenger: Yes, only these two of my carry-on baggage.

Check-in: All right. Now you can go to the boarding gate's room and wait.

Passenger: Thank you so much! Have a good day!
Check-in: So, do you! Here is your boarding pass. Remember, that you are obliged to be at the gate one hour prior to boarding time. Don't be late please. Our flight crew will have some special instructions for take-off and landing.

\section{Sample of Conversation 2:}

Here are some communicative phrases to practice announcing and giving information about flight.

Crew or Capitan greetings: Good morning (day, evening), ladies and gentlemen!

We sincerely welcome you aboard the airplane Rai-jet (airplane type) of the airline Muldy-airlines (airline name), which flies to New York. Please place all your belongings under a front chair or on shelves. Thank you for your cooperation.

Board assistant's or Capitan's instructions: Good morning (day, evening), ladies and gentlemen! We apologize for the flight delay and inconvenience caused to you. We sincerely welcome you aboard the airplane 347-airrobus of the Rink airline, which flies to Rime to Italy. Flight time 2 hours 10 minutes. Airplane commander William Sword. Senior Flight Attendant Jack Frankey. Our crew will do their best to make your flight enjoyable and comfortable. Ladies and Gentlemen! Please pay attention to the monitors and carefully watch the video showing the safety rules on board the aircraft. Thank you for your cooperation.

After the introduction of "The professionally oriented Aviation English learning program for the aviation industry students", we've got the following changes in the Aviation English communicative language skills: at the final stage of the study, a comparative characterization of the level of communicative language skills of future aviation industry professionals was compared with the ascertaining stage. For the realization of the research we used the methodology described in Section "proposed methods and approaches" to find out the changes that have occurred in the levels of communicative language skills of 
future aviation industry professionals in the experimental groups. The overall integrative indicator of communicative language skills of future aviation industry professionals was determined according to the Aviation English communicative language skills criteria: a language proficiency testing process develop; ELEs and SMEs gathered to work on the same air; Teams of ELEs/SMEs interlocutors made up; Teams of ELEs/SMEs raters made up; Interlocutors and Raters trainee; Administrative and security procedures develop; Trailing and surveys carried out; Record-keeping system develop; Clear and documented separation of both training and testing services provided by CIPE), which is attaining and maintaining the language proficiency defined as ICAO Operational Level 4 (ICAO) (Table 3).

The analysis of the tasks of the control phase of the experiment made it possible to compare the results obtained at the beginning and end of the experimental work and to record a significant increase in the levels of future aviation industry professionals' communicative language skills from the experimental contingent, as well as certain changes in the control groups (CG). Comparative quantitative data on the levels of future aviation industry professionals' communicative language skills in the control and experimental groups (EG) are shown in Table 4.

Table 3. Systemized descriptors from the ICAO Rating Scale at Level 4

\begin{tabular}{|c|c|}
\hline Descriptors & Explanations \\
\hline Vocabulary & $\begin{array}{l}\text { Vocabulary includes individual words and fixed expression. Vocabulary can be classified by the } \\
\text { domains of meaning to which it refers. While memorizing phraseologies is neither an acceptable } \\
\text { means of demonstrating language proficiency nor an effective or recommended language learning } \\
\text { strategy, it is undeniable that context is a relevant factor in language proficiency. }\end{array}$ \\
\hline Pronunciation & $\begin{array}{l}\text { The six levels of pronunciation descriptors are applicable at all levels to native and non-native } \\
\text { speakers. This implies that native English speakers may demonstrate Elementary Level } 2 \text { proficiency } \\
\text { if their regional dialect is so localized that it is not readily understood by those outside of that } \\
\text { particular region. On the other hand, speakers whose speech patterns clearly identify them as } \\
\text { non-native speakers (having a so-called "accent") may demonstrate Expert Level } 6 \text { proficiency. }\end{array}$ \\
\hline Grammatical structures & $\begin{array}{l}\text { Relevant grammatical structures and sentence patterns are determined by language functions } \\
\text { appropriate to the task. Users may refer to the communicative aeronautical language functions, to the } \\
\text { list of controller communicative tasks and to the classification of basic and complex structures in } \\
\text { Appendix B of Doc } 9835-\mathrm{AN} / 435 \text { for guidance [32]. Language teaching specialists generally } \\
\text { categorize grammatical errors into two classes: "global" and "local". Global errors are those which } \\
\text { interfere with meaning; local errors are those which do not interfere with meaning. }\end{array}$ \\
\hline Fluency & $\begin{array}{l}\text { For our purposes, fluency is intended to refer to the naturalness of the flow of speech production, the } \\
\text { degree to which comprehension is hindered by any unnatural or unusual hesitancy, distracting starts } \\
\text { and stops, distracting fillers (em ...huh ... er ...) or inappropriate silence. Levels of fluency will be } \\
\text { most apparent during longer utterances in an interaction. They will also be affected by the degree of } \\
\text { expectedness of the preceding input which is dependent on familiarity with scripts. }\end{array}$ \\
\hline Comprehension & $\begin{array}{l}\text { This skill refers to the ability to listen and understand. In air traffic control communications, pilots } \\
\text { rely on the clear and accurate information provided by controllers for safety. It is not sufficient for air } \\
\text { traffic controllers to be able to handle most pilot communications; they must be ready for the } \\
\text { unexpected. Similarly, pilots must be able to understand air traffic controller instructions, especially } \\
\text { when these differ from what a pilot expects to hear. It is during complications in aviation that } \\
\text { communications become most crucial, with a greater reliance upon plain language. While } \\
\text { comprehension is only one out of six skills in the Rating Scale, it represents half of the linguistic } \\
\text { workload in spoken communications. }\end{array}$ \\
\hline Interactions & $\begin{array}{l}\text { Because radiotelephony communications take place in a busy environment, the communications of } \\
\text { air traffic controllers and pilots must not only be clear, concise and unambiguous, but appropriate } \\
\text { responses must be delivered efficiently and a rapid response time is expected. The interactions skill } \\
\text { refers to this ability, as well as to the ability to initiate exchanges and to identify and clear up } \\
\text { misapprehension s. }\end{array}$ \\
\hline
\end{tabular}

Referenced from: MANUAL on the English Language Proficiency Assessment (ICAO language proficiency requirements) Electronic resource: https://www.caa.md/files/2014_03/616.pdf

Table 4. The levels of communicative language skills of future aviation industry professionals in the control and experimental groups (\%)

\begin{tabular}{|c|c|c|c|c|c|}
\hline \multirow{2}{*}{ Levels } & \multicolumn{3}{|c|}{ Ascertaining stage } & \multicolumn{2}{|c|}{ Formative stage } \\
\hline & EG & CG Q1 & CG Q2 & EG & CG Q1 \\
\hline High & - & - & - & 28.5 & 6.8 \\
\hline Sufficient & - & - & 17 & 33.4 & 15.6 \\
\hline Average & 31.9 & 28.0 & 57.3 & 21.6 & 48.4 \\
\hline Low & 68.1 & 72.0 & 23 & 16.5 & 30.2 \\
\hline
\end{tabular}


The results in the table 4 show quantitative changes in the levels of future aviation industry professionals' communicative language skills in both groups. However, the positive dynamics of increasing levels of future aviation industry professionals' communicative language skills are statistically significant only in the experimental group of students. The data obtained and presented in the table convincingly prove that in the conditions of using the experimental work of future aviation industry professionals' communicative language skills, a high level of future aviation industry professionals' communicative language skills has been achieved. As we can see from the table 4, the differences in the quantitative data of students of control groups Q1 (ascertaining stage) and Q2 (forming stage) were insignificant. Consequently, the traditional English teaching methods did not contribute to the high level of future aviation industry professionals' communicative language skills.

An analysis of the level dynamics showed that $28.5 \%$ of the experimental and $6.8 \%$ of students in the control groups (Q2) reached a high level of communicative language skills, whereas at the initial stage no students in both groups were found at this level. As we can see, the positive impact of the implemented program of future aviation industry professionals' communicative language skills of the experimental group improved their communicative language skills. Thus, if there were no high and sufficient levels of future aviation industry professionals' communicative language skills at the beginning of the experiment, then at the end of the experimental work, these results changed and were respectively $28.5 \%$ and $33.4 \%$ (EG) and $6.8 \%$ and $15.6 \%$, respectively (CG). The average level at the initial stage of the experiment was $31.9 \%$ (EG) and $28 \%(\mathrm{CG})$, while the final results were $21.6 \%$ (EG) and $48.4 \%$ (CG). The shifts in low-level indicators are particularly evident. If at the beginning of the experiment they were respectively $68.1 \%(\mathrm{EG})$ and $72 \%(\mathrm{CG})$, then at the end these results decreased significantly in the experimental groups $-16.5 \%$ (EG) and only $30.2 \%$ were in the control groups, which can be explained by the spontaneous socialization, as well as the peculiarities of the influence of the traditional English language teaching process on the future aviation industry professionals' communicative language skills in the control group.

\section{Discussion}

The problem of the Aviation English Teaching has been discussed by modern scientists in different aspects: A. Borowska, M. Lączek, P. Szerszeń indicated the Basic types of learning through modern technologies in specialized contexts [30]; D. Bowen, worked over the contextualizing Pronunciation Practice in the ESOL Classroom [10]; M. Mc Grath provided the recommendations for "A Training Course for Teachers of Aviation Technical English" [18]; A. Kukovec studied the
Teaching Aviation English and Radiotelephony communication in line with the newly established International Civil Aviation Organization [19]; O. Petrashchuk and O. Vasiukovych analysed the linguistic profile of Aviation English language within the training courses [31]. All the proposed investigations paid their attention to Aviation English Teaching, but these works required more concrete investigations on program content and structure of future aviation industry professionals. All of these studies are concerned to different aspects of Aviation English Teaching, Aviation Technical English etc. Some authors worked over recommendations for Training Course for Teachers of Aviation Technical English but do not present the communicative training method or exercises. The typology of O. Kovtun [27] is very useful for the choice of the most appropriate exercises to use in the context of communicative and competence approach, which were leading within our research.

The expected results of the study predicted positive dynamics of changes in the levels of understanding, perception and mastery of professionally oriented English. We followed these changes only after the implementation of "The professionally oriented Aviation English learning program" for the aviation industry students. Unlike the communicative exercises that were practiced earlier, the program was characterized by its structure and greater adaptability to communication-oriented methods of Aviation English Teaching.

In view of this, our study was the first to offer a comprehensive program describing the methods and exercises for the effective mastering of professionally oriented aviation English by future aviation professionals. The provided research showed that in Aviation industry the professionally oriented Aviation English Teaching has certain peculiarities caused by the choice of the student of the relevant specialty. Thus, future pilots, air traffic controllers, engineers of the aviation industry have special requirements for mastering them in special aviation English. In accordance with paragraph 1, 29 and 4, Amendments 164 to Appendix A of Doc 9835-AN/435 [32], adopted by the International Civil Aviation Organization (ICAO) on November 27, 2003, starting March 5, 2008, airplane and helicopter pilots, air traffic controllers and air station operators should be able to communicate in English and understand it at the fourth working level of the six identified (the fourth level is minimum sufficient for language support of international flights $\mathrm{x}$ routes). The working level provides effective communication on general, specific and work-related topics. The ICAO Qualification Scale was developed to develop the requirements for mastering the common English language research group PRICE SG (Proficiency Requirements in the Common English Study Group), initiated by the ICAO Air Navigation Commission. The emergence of these documents is the result of an analysis of aviation incidents, one of the reasons is lack of 
language proficiency to fulfil their functional responsibilities.

Thus, Aviation English language teaching is of special importance for aviation professionals training as they are a prerequisite for international flights, defined by ICAO for all countries. The implemented research made it possible to distinguish positive practice of introduction the "The professionally oriented Aviation English learning program for the aviation industry students", the content of which was developed on the basis of Guidelines for Aviation English Training Programmes and with modern practice of communicative training exercises and when the three main approaches were considered (competence, communicative and contextual).

\section{Conclusions}

The study proved out the importance of the Aviation English teaching of future aviation industry professionals, the effective approaches to professionally oriented Aviation English teaching are distinguished as the dominative; the communicative training methods, which were suggested to improve English language proficiency of future aviation industry professionals has proved out its quality and effectiveness. "The professionally oriented Aviation English learning program for the aviation industry students", which was developed by the author in the process of investigation promotes further proficiency of future aviation industry professionals and is a significant in contributing to air transportation safety.

The development of English-language communicative language skills of future aviation industry professionals to the high point demands the organization of a qualitative foreign-language educational milieu of universities, which should help students to adapt to the English-language academic, professional and information environment. Intensive development of teaching and informational technologies in the context of educational dimension requires future aviation industry professionals' constant and active implementation in the daily practice of teaching, especially communicative training exercises. Therefore, the suggested investigation doesn't not completely reveal all the aspects of professionally oriented English teaching, as the critical approach in Aviation English teaching is not analysed, the problems of cultural interaction are not discussed, thus these points will be the subject of further scientific researches.

\section{Acknowledgments}

The authors thank the National Aviation University for given opportunity to conduct student surveys. All the participants who took part in the research knew about the experiment and were informed about it by the author and administration. They were also informed about terms and conditions of the research carried out and all of the participants of the research agreed to participate in it voluntarily.

\section{REFERENCES}

[1] State of Global Aviation Safety, ICAO, Safety Reports, 2019. Online available from:https://www.icao.int/safety/Pages/Sa fety-Report.aspx

[2] Terminology of European Education and Training Policy: a selection of 100 key terms / CEDEFOP, European Centre for the Development of Vocational Training, Luxembourg, Office for Official Publications of the European Communities, 2008.

[3] European Union Aviation Safety Agency. Online available from https://www.easa.europa.eu/

[4] S. Höhne. IT in general Aviation: Pen and Paper vs. Bits and Bytes, Germany, Hannover, Shhoehne.net, 2014.

[5] P. Krämer. Chicago Convention, 50 ${ }^{\text {th }}$ Anniversary Conference, Chicago, October 31 - November 1, 1994. Online available from: https://www.wipo.int/edocs/lexdocs/ treaties/en/icao-ca/trt_icao_ca_001en.pdf

[6] European Aviation - A framework for driving performance improvement, High Level Group for the Future European Aviation Regulatory Framework Founded by EC-Commissioner Jacques Barrot, 2007. Online available from:

http://ec.europa.eu/transport/air_portal/traffic_management/ traffic_management/ses/doc/2007_07_06_hlg_report.pdf

[7] FIPF Liege, Belgium, 2016. Online available from: https://www.mije.com/auberge-jeunesse-paris/congres-fipfde-liege-2016

[8] EDULEARN2018. Palma de Majorca, Spain; Ibero-American World Cadiz, Spain 2018, 2018. Online available from: https://iated.org/edulearn18/announcement

[9] A. Schleicher. Preparing Teachers and Developing School Leaders for the 21st Century: Lessons from around the World, Paris, OECD Publishing, 2012. DOI: https://doi.org/10.1787/9789264174559-en.

[10] D. J. Bowen. Contextualizing Pronunciation Practice in the ESOL Classroom. Teaching English as a Second or Foreign Language. M. Celce-Murcia \& L. McIntosh [Eds], Los Angeles: Newbury House Publishers, Inc., 1989.

[11] O. Tarnopolsky. Constructivist Blended Learning Approach to Teaching English for Specific Purposes, A. Borowska [Ed.], London, Versita, 2012.

[12] H. Widła, \& M. Twardoń. Computer Based Teaching in Distance Learning Department of Philological Faculty, Journal of Medical Informatics and Technologies/ Supplement: Distance Learning Technologies, Vol. 9, 2005.

[13] M. Liu, \& R. Kleinsasser. Fostering online professional development between EFL preservice and in-service teachers: Affordances and challenges, Teaching and learning, Vol. 38, No. 2, 29-64, 2014. 
[14] Z. Takacs, E. Swart, \& A. Bus. Benefits and Pitfalls of Multimedia and Interactive Features in Technology Enhanced Storybooks: A Meta-Analysis, Review of Educational Research, Vol. 85, No. 4, 698-739, 2015. DOI: 10.3102/0034654314566989.

[15] N. Mikheeva, \& N. Dvoryadkina. Use of electronic teaching and methodical complex based on MOODLE educational platform for profession-oriented English language training of Russian cosmonauts. In L. Gómez Chova, A. López Martínez \& I. Candel Torres (Eds.), EDULEARN16: Proceedings of the 8th annual International Conference on Education and New Learning Technologies, Barcelona, Spain, IATED Academy, 2016.

[16] P. H. Ragan. Aviation English: An Introduction, Journal of Aviation/Aerospace Education \& Research, Vol. 7, No. 2, 1997. Online available from http://commons.erau.edu/jaaer/ vol7/iss $2 / 1$

[17] D. Estival, \& B. Molesworth, Radio Miscommunication: EL2 Pilots in the Australian General Aviation environment, Linguistics and the Human Sciences, Vol. 5.3, 351-378, 2012.

[18] M. McGrath. A Training Course for Teachers of Aviation Technical English, Edinburgh, Edinburgh University Press, 2007.

[19] A. Kukovec. Teaching Aviation English and Radiotelephony communication in line with the newly established International Civil Aviation Organization language proficiency requirements for pilots, Inter Alia, 2008.

[20] Guidelines for Aviation English Training Programmes, ICAO (International Civil Aviation Organization), University Street, Montréal, Quebec, Canada, 2009. Online available from: https://www.icao.int/safety/lpr/Documents/ 323 en.pdf

[21] S.T.S. Ahmed, \& S.V. Pawar. Communicative language skills in English as a foreign language: Its meaning and the pedagogical considerations for its development. The Creative Launcher, Chat and Learn: Effectiveness of Using WhatsApp as a Pedagogical Tool to Enhance EFL Learners Reading and Writing Skills, Vol. 2, No. 4, 301-312, 2018.

[22] M. Canale, \& M. Swain. Theoretical bases of communicative approaches to second language teaching and testing. Applied Linguistics, Vol. 1, 1-47, 1980.
[23] V. L. Skalkin. The foundations of teaching foreign oral speech, Moscow, Russkiy yazyk, 1981.

[24] Ye. I. Passov. Communicative method of teaching foreign language speaking ( $2^{\text {nd }}$ ed., rev.), Moscow, Prosvescheniye, 1991.

[25] N.I. Melnyk. Peculiarities of future pilots English language learning: contextual translation of aviation terminology, Air 2019: XIV International scientific-technical Conf., April 23-25, Kyiv, 2019. Online available from: http://conference .nau.edu.ua/index.php/AVIA/AVIA2019/paper/view/6160/ 4907

[26] N. Mikheeva, M. Petrova, \& A. Khabryankina Professional-Oriented English Language Teaching of the Future Specialist in Higher Institutions, Conference: XVIII International Conference Professional culture of the specialist of the future,

At: Saint-Petersburg, Vol. LI, n. P.,

2018. Online available from: https://www.futureacademy.or g.uk/files/images/upload/18thPCSF2018F134.pdf

[27] A. Bogush, \& O. Kovtun. Discourse: Radio Exchange of Civil Aviation: a psycholinguistic aspect, Psiholingvistika Psycholinguistics, Vol. 25, No. 1, 11-32, 2019. DOI: https://doi.org/10.31470/2309-1797-2019-25-1-11-32

[28] N. V. Yazikova. Collection of tasks and assignments on methods of teaching foreign languages, 1977.

[29] M. Celce-Murcia, \& F. Rosenzweig. Teaching vocabulary in the ESL classroom. In M. Celce-Murcia and L. McIntosh [Eds], Teaching English as a Second or Foreign Language. Rowley, Ma.: Newbury House, 1979.

[30] A. Borowska, M. Lączek, \& P. Szerszeń. Wydawnictwo Naukowe Instytutu Komunikacji Specjalistycznej i Interkulturowej Uniwersytet Warszawski Warszawa, 2015. Online available from: https://www.academia.edu/2860672 8/Changing Perspectives on_Aviation_English_Trainin

[31] O. Petrashchuk, \& O. Vasiukovych. Rationale for linguistic profile of Aviation English language training course, NAU Proceedings, Vol. 2, No. 65, 112-119, 2015.

[32] ICAO. Manual on the Implementation of the ICAO Language Proficiency Requirements, Doc 9835-AN/453, ICAO, [Second ed.], Canada, 2010. Online available from: https://skybrary.aero/bookshelf/books/2497.pdf 